\title{
Quantum efficiency of photosystem II and production of orange under salt stress and nitrogen fertilization
}

\author{
Jônatas R. M. de Sousa ${ }^{1}$, Hans R. Gheyi ${ }^{2}$, Marcos E. B. Brito ${ }^{3}$, \\ Claudivan F. de Lacerda ${ }^{4}$, Francisco V. da Silva ${ }^{5}$ \& Frederico A. L. Soares ${ }^{6}$ \\ ${ }^{1}$ Universidade Federal de Campina Grande/Departamento de Engenharia Agrícola. Campina Grande, PB. E-mail: jonatasraulyno@gmail.com \\ (Corresponding author) \\ ${ }^{2}$ Universidade Federal do Recôncavo da Bahia/Núcleo de Engenharia de Água e Solo. Cruz das Almas, BA. E-mail: hans@pq.cnpq.br \\ ${ }^{3}$ Universidade Federal de Campina Grande/Unidade Acadêmica de Ciências Agrárias. Pombal, PB. E-mail: marcoseric@ccta.ufcg.edu.br \\ ${ }^{4}$ Universidade Federal do Ceará/Departamento de Irrigação e Drenagem. Fortaleza, CE. E-mail: cfeitosa@ufc.br \\ ${ }^{5}$ Universidade Federal Rural do Semi-Árido/Departamento de Ciências Ambientais. Mossoro, RN. E-mail: valfisio@hotmail.com \\ ${ }^{6}$ Instituto Federal de Educação, Ciência e Tecnologia Goiano. Rio Verde, GO. E-mail: fredalsoares@hotmail.com
}

\section{Key words:}

Citrus spp.

physiology

salt stress

\begin{abstract}
A B S T R A C T
This study aimed to evaluate the salt tolerance of 'Mimo do Céu' orange grafted onto three rootstocks using physiological parameters such as maximum quantum efficiency of photosystem II (PSII) and the production of fruits. It also evaluated the effectiveness of increased nitrogen $(\mathrm{N})$ fertilization in reducing the effects of salt stress. Two concomitant experiments were carried out under controlled conditions, using drainage lysimeters. The Experiment I evaluated the effects of the application of five levels of saline water on three combinations of scion-rootstocks grafted with 'Mimo de Ceu' orange, in a randomized block design with three replicates in a $5 \times 3$ factorial scheme. The Experiment II evaluated the application of two N levels ( 100 and $200 \%$ of recommendation) in three scion-rootstock combinations irrigated with water of electrical conductivity of $3.0 \mathrm{dS} \mathrm{m}^{-1}$, in a $3 \times 2$ factorial scheme, with three replicates. The maximum quantum efficiency of PSII was inhibited in citrus plants under salt stress. 'Mimo do Ceu' orange grafted onto 'Common' Rangpur lime has higher yield potential. The increase in $\mathrm{N}$ dose did not reduce the deleterious effects of water salinity on fruit production.
\end{abstract}

\section{Palavras-chave: \\ Citrus spp. \\ fisiologia \\ estresse salino}

\section{Eficiência quântica do fotossistema II e produção de laranjeira sob estresse salino e adubação nitrogenada}

\section{R E S U M O}

Objetivou-se, com este trabalho, avaliar a tolerância ao estresse salino da laranjeira 'Mimo do Céu' enxertada em três porta-enxertos utilizando como parâmetros fisiológicos, a eficiência quântica do fotossistema II e a produção de frutos. Também se avaliou a eficiência máxima do incremento da adubação nitrogenada na redução dos efeitos do estresse salino; para tanto foram realizados dois experimentos concomitantes em condições controladas e com auxílio de lisímetros de drenagem. No Experimento I foram estudados em blocos casualizados com três repetições, em esquema fatorial 5 × 3, cinco níveis de salinidade da água e três combinações de copa/porta-enxerto e no Experimento II estudou-se a aplicação de duas doses de N (100 e 200\% da recomendação) em plantas das três combinações de copa/porta-enxerto irrigadas com águas de condutividade elétrica de 3,0 $\mathrm{dS} \mathrm{m}^{-1}$, em esquema fatorial $3 \times 2$ com três repetições. A eficiência máxima quântica do PSII foi inibida nas plantas cítricas com estresse salino; já o aumento do teor salino da água de irrigação reduz a produção de frutos e a laranjeira 'Mimo do Céu' enxertada no Limoeiro Cravo 'Comum' possui maior potencial produtivo. $\mathrm{O}$ aumento na fertilização nitrogenada não reduziu os efeitos da salinidade sobre a produção total de frutos. 


\section{INTRODUCTION}

Citrus stands out as one of the main crops in the Brazilian fruticulture, placing the country as the largest global producer of orange with planted area of 729,583 ha and production of $18,012,560 \mathrm{t}$ of fruits. Approximately $80 \%$ of the production of citrus in Brazil is concentrated in the Southeast region, in the state of São Paulo; however, the Northeast presents itself as the second largest producing region in the country, contributing with $11 \%$ of the national production, although it has the lowest orange yield $\left(14.79 \mathrm{t} \mathrm{ha}^{-1}\right)$ compared with the other regions: North (16.04 t ha $\left.{ }^{-1}\right)$, Midwest (17.82 $\left.\mathrm{t} \mathrm{ha}^{-1}\right)$, South $(22.32 \mathrm{t}$ $\mathrm{ha}^{-1}$ ) and Southeast (27.91 t ha-1) (IBGE, 2013). Such low yield observed in the Northeast region results from the lower use of technologies by the farmers. Irrigation management controlling water deficit in the periods of dry spells, negative water balance, can contribute to the increment in the yield of the region; however, inadequate irrigation management, combined with the use of waters with high concentration of salts, increases the risk of soil salinization and can negatively influence crop yield.

The literature often reports the sensitivity of various citrus genotypes to salinity, which, according to Singh et al. (2003), have threshold salinity of $2.0 \mathrm{dS} \mathrm{m}^{-1}$ in the soil saturation extract. Higher values reduce plant growth and cause physiological alterations (Silva et al., 2014) due to water stress, specific ionic toxicity and ion imbalance (Habibi \& Amiri, 2013).

For Brito et al. (2014), citrus tolerance to salinity must be evaluated considering the scion-rootstock combination; this is particularly important because citrus are more sensitive to chloride $\left(\mathrm{Cl}^{-}\right)$than to sodium $\left(\mathrm{Na}^{+}\right)$and the selection of rootstock is fundamental in the response of the plant to the excess of salts, since the restriction in the absorption of chloride can contribute to obtaining tolerant citrus genotypes, capable of producing economically viable yields under saline conditions (Syvertsen \& Sanchez, 2014).

The supply of nitrogen $(\mathrm{N})$ in the nitric form $\left(\mathrm{NO}_{3}^{-}\right)$above the recommended dose can balance cations and anions and improve the absorption of nutrients by plants. On the other hand, the application of $\mathrm{N}$ in the ammoniacal form $\left(\mathrm{NH}_{4}^{+}\right)$can contribute to a greater absorption of anions and, if the soil has high contents of chlorides, as observed in most salt-affected soils, the former will be preferentially absorbed, causing lower damages to plants.

Genotypes tolerant to abiotic stress can be identified through the technique of chlorophyll fluorescence; this technique allows determining parameters of photochemical efficiency of the photosystem (PSII), which are related to the use of light energy by the PSII. The literature reports chlorophyll fluorescence as a physiological parameter efficient at the identification of absence or presence of damages in the photosynthetic process, notably in plants exposed to environmental stresses (Falco et al., 2011).

Thus, this study aimed to evaluate the maximum quantum efficiency of photosystem II and the production of fruits of citrus scion-rootstock combinations under saline water irrigation and $\mathrm{N}$ doses.

\section{Material ANd Methods}

Two experiments were simultaneously conducted in a protected environment (screened, without plastic cover) at the Academic Unit of Agricultural Engineering, linked to the Center of Technology and Natural Resources (CTRN) of the Federal University of Campina Grande (UFCG), in Campina Grande-PB, Brazil (7 15’ 18” S; 35 52’ 28” W; $550 \mathrm{~m}$ ). The climate in the region is As, according to Köppen's classification.

Experiment I evaluated the tolerance to saline stress of 'Mimo do Céu' orange grafted onto three rootstocks (Table 1), using a randomized block design, in a $5 \times 3$ factorial scheme, which corresponded to five levels of irrigation water salinity (S1 - water with electrical conductivity - ECw of $0.6 \mathrm{dS} \mathrm{m}^{-1}$, control; S2 - $1.2 \mathrm{dS} \mathrm{m}^{-1}$; S3 - $1.8 \mathrm{dS} \mathrm{m}^{-1}$; S4 - $2.4 \mathrm{dS} \mathrm{m}^{-1}$ and $\mathrm{S} 5-3.0 \mathrm{dS} \mathrm{m}^{-1}$ ) applied in three scion-rootstock combinations, described in Table 1.

Experiment II consisted in the evaluation of tolerance to saline stress of 'Mimo do Céu' orange grafted onto three rootstocks, as described in Table 1 , subjected to irrigation with water of ECw of $3.0 \mathrm{dS} \mathrm{m}^{-1}$ and $\mathrm{N}$ fertilization with 100 and $200 \%$ of the recommendation proposed by Novais et al. (1991) for experiments in controlled environment. The experiment was conducted in $3 \times 2$ factorial scheme, which corresponded to three scion-rootstock combinations and two $\mathrm{N}$ doses, with three replicates and one plant per plot. Urea ( $45 \%$ of $\mathrm{N}$ ) was used as the $\mathrm{N}$ source, which has the advantages of high $\mathrm{N}$ concentration and lower cost/benefit ratio (Marchesan et al., 2011).

Evaluations were performed in plants of two years of age after transplantation, encompassing the period between preflowering and the first commercial production, from July 30 to December 30, 2013.

Both experiments used drainage lysimeters with height of $0.70 \mathrm{~m}$, diameter of $0.57 \mathrm{~cm}$ and volumetric capacity of 150 $\mathrm{L}$, distributed in single rows with spacing of $1.5 \mathrm{~m}$ between rows and $1 \mathrm{~m}$ between plants. The lysimeters were filled with a 0.10 -m-thick layer of crushed stone $(<5 \mathrm{~mm})$, followed by a 0.10 - $\mathrm{m}$-thick layer of sand in order to facilitate the drainage of excess water from irrigation, and a 0.40 -m-thick layer of soil material, corresponding to a mass of $238 \mathrm{~kg}$ of soil and 4.76 $\mathrm{kg}$ of humus, mixed with the superficial part of the soil. The top $0.10 \mathrm{~m}$ of the surface of the pots remained free in order to facilitate irrigation and cultural practices.

Table 1. Studied combinations of scion-rootstock under saline water irrigation during the pre-flowering stage and first production in lysimeters

\begin{tabular}{cl}
\hline Scion & \multicolumn{1}{c}{ Rootstock $^{*}$} \\
'Mimo do Céu' & RS1 - TSKC ('Common Sunki' mandarin (Citrus sunki (Hayata) hort. ex Tanaka)) x TRENG (Poncirus Trifoliata 'English') - 256 \\
orange & RS2 - LCRC ('Common' Rangpur lime (Citrus limonia L. Osbeck)) \\
\hline *From the Citrus Breeding Program (PMG - Citros) of the Embrapa Cassava and Fruits
\end{tabular}

*From the Citrus Breeding Program (PMG - Citros) of the Embrapa Cassava and Fruits 
Table 2. Physical-hydraulic and chemical properties of the soil used in the experiment

\begin{tabular}{|c|c|c|c|c|c|c|c|c|c|c|}
\hline \multirow{3}{*}{$\begin{array}{l}\text { Density } \\
\mathbf{k g ~ d m}^{-3}\end{array}$} & \multirow{3}{*}{$\begin{array}{c}\text { Total porosity } \\
\%\end{array}$} & \multirow{2}{*}{ Sand } & \multirow{2}{*}{ Silt } & \multirow{2}{*}{ Clay } & \multicolumn{4}{|c|}{ Sorption complex } & \multirow{3}{*}{$\mathrm{pH}_{\mathrm{sp}}$} & \multirow{3}{*}{$\begin{array}{l}\mathrm{EC}_{\mathrm{se}} \\
\mathrm{dS} \mathrm{m}^{-1}\end{array}$} \\
\hline & & & & & $\mathrm{Ca}^{2+}$ & $\mathrm{Mg}^{2+}$ & $\mathrm{Na}^{+}$ & $\mathbf{K}^{+}$ & & \\
\hline & & & $\mathrm{g} \mathrm{kg}^{-1}$ & & \multicolumn{4}{|c|}{$\mathrm{cmol}_{\mathrm{c}} \mathrm{kg}^{-1}$} & & \\
\hline 1.42 & 49.47 & 734 & 168 & 98 & 1.88 & 3.13 & 1.64 & 0.06 & 4.72 & 0.66 \\
\hline
\end{tabular}

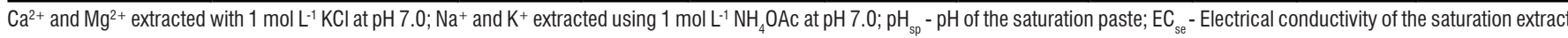

The soil used in the experiment was classified as non-saline, non-sodic, eutrophic Regolithic Neosol, with sandy loam texture, and was collected from the layer of $0-30 \mathrm{~cm}$, in the district of São José da Mata, Campina Grande-PB. Its physicalhydraulic and chemical characteristics are shown in Table 2.

During the experiment, $\mathrm{N}, \mathrm{P}$ and $\mathrm{K}$ fertilizations were based on the recommendations of Novais et al. (1991) for experiments in controlled environments and performed monthly, as shown in Table 3. Additional $\mathrm{N}$ fertilization in the plants from Experiment II was always performed 15 days after the fertilization of $100 \%$, i.e., the additional $100 \%$ was applied 15 days after the recommended fertilization.

The levels of water electrical conductivity (ECw) were obtained through the dissolution of commercial $\mathrm{NaCl}$ (without iodate) and confirmed using a benchtop conductivity meter (Digimed DM-32). Irrigations were performed according to plant water demand, with intervals of two to three days, based on plant water consumption, which was determined through soil water balance, given by the applied volume minus the volume drained in the previous irrigation, and adding a leaching fraction (LF) of 0.1 .

At the end of the experiment, i.e., 150 days after the beginning of flowering, in both experiments, the following parameters were determined: initial fluorescence (Fo), maximum fluorescence $(\mathrm{Fm})$, variable fluorescence $(\mathrm{Fv})$ and maximum quantum efficiency of PSII (Fv/Fm), using a fluorometer, Model PEA (Plant Efficiency Analyser, Hansatech Norfolk, UK), measured in the third leaf counted from the

Table 3. Fertilization management performed during the experiment

\begin{tabular}{|c|c|c|c|}
\hline & $\begin{array}{l}\text { Nitrogen } \\
\text { (N) }\end{array}$ & $\begin{array}{l}\text { Phosphorus } \\
\text { (P) }\end{array}$ & $\begin{array}{l}\text { Potassium } \\
\text { (K) }\end{array}$ \\
\hline Recommendation ( $\mathrm{mg} \mathrm{kg}^{-1}$ of soil) & 100 & 300 & 150 \\
\hline Fertilizer source & Urea & MAP & $\mathrm{K}_{2} \mathrm{SO}_{4}$ \\
\hline Fertilization (g per lysimeter) & 21.5 & 121.1 & 72.2 \\
\hline Monthly amount (g month $\left.{ }^{-1}\right)$ & 1.8 & 10.1 & 6.1 \\
\hline
\end{tabular}

apex of the branch, pre-adapted to the dark with leaf tweezers between 6 and $7 \mathrm{~h}$ for $30 \mathrm{~min}$, following the methodology described in Konrad et al. (2005). Total fruit production (TFP) was obtained through the weighing of the harvested fruits on a scale with precision of $0.001 \mathrm{~g}$.

The obtained results were subjected to analysis of variance ( $F$ test, $\mathrm{p}<0.05$ ) and polynomial regression analysis (linear and quadratic) for the factor irrigation water salinity and Tukey test for the factor scion-rootstock, using the statistical program SISVAR (Ferreira, 2011).

\section{Results AND Discussion}

In the analysis of variance (Table 4 ), there was significant effect $(p \leq 0.01)$ of the salinity levels for the parameters of chlorophyll fluorescence, Fo, Fm, Fv and Fv/Fm. For the rootstocks and their interaction with the salinity levels, no significant effects $(p>0.05)$ were observed. These results differ from those obtained by López-Climent et al. (2008), who studied five different citrus genotypes ('Swingle Citrumelo', 'Carrizo citrange', 'C35 citrange', 'Cleopatra mandarin' and 'FA5') treated three times a week with nutrient solution at 60 $\mathrm{mM}$ of $\mathrm{NaCl}$ in a period of 90 days and concluded, through the evaluation of the effects of salinity on the photochemical efficiency of PSII, that FA5 was the most tolerant genotype. This discrepancy can be explained, at least partially, by the genetic characteristics of the compared materials and by the studied salinity levels.

Fo showed increasing linear tendency with the increment in salinity levels, from 344 to 608 between 0.6 and $3.0 \mathrm{dS} \mathrm{m}^{-1}$, which corresponded to an increase of $31.97 \%$ per unit increase in ECw (Figure 1A). According to Rumeau et al. (2007), plants under abiotic stress, such as saline stress, have their initial fluorescence increased due to damages in the D1 proteins of the photosystem II (PSII) and through non-photochemical reduction of the quinone by $\mathrm{NADPH}$, available in the

Table 4. Summary of the analysis of variance for the variables initial fluorescence (Fo), maximum fluorescence (Fm), variable fluorescence (Fv), quantum efficiency of photosystem II (Fv/Fm) and total fruit production (TFP) under different salinity levels $(\mathrm{ECW})$ and combinations of scion-rootstock (RS) of citrus grafted with 'Mimo do Céu' orange (Citrus sinensis OSBECK var. Mimo) at 150 days after the beginning of flowering

\begin{tabular}{|c|c|c|c|c|c|c|}
\hline \multirow{2}{*}{ Source of variation } & \multirow{2}{*}{ DF } & \multicolumn{5}{|c|}{ Mean Square } \\
\hline & & $\mathrm{Fo}^{1}$ & $\overline{F m}$ & Fv & $\mathrm{Fv} / \mathrm{Fm}$ & TFP1 \\
\hline Salinity (ECw) & 4 & $116082.988^{* *}$ & $399487.889^{\star \star}$ & $902822.577^{\star \star}$ & $0.081^{* *}$ & $7805376.744^{* *}$ \\
\hline Linear regression & & $395328.117^{* *}$ & $1597951.556^{* *}$ & $3480766.513^{* *}$ & $0.288^{* *}$ & $29158543.699^{*}$ \\
\hline Quadratic regression & & $45048.618^{\text {ns }}$ & $43134.689^{\mathrm{s}}$ & $118151.145^{\urcorner \mathrm{s}}$ & $0.031^{* *}$ & $1343595.208^{1 \mathrm{~s}}$ \\
\hline Rootstock (RS) & 2 & $19079.444^{\text {ns }}$ & $43134.689^{\mathrm{ss}}$ & $22869.272^{\text {ns }}$ & $0.003^{\text {ns }}$ & $15191409.8^{* *}$ \\
\hline ECw $x$ RS & 8 & $7343.186^{1 s}$ & $26950.272^{\mathrm{ns}}$ & $15061.869^{\text {ns }}$ & $0.001^{\text {ns }}$ & $246646.744^{\text {ns }}$ \\
\hline Block & 2 & 8083.084 & 24758.689 & 36191.339 & 0.003 & 227141.267 \\
\hline Residue & 28 & 10280.084 & 53464.998 & 35825.934 & 0.002 & 420757.719 \\
\hline CV & & 9.86 & 12.44 & 13.7 & 7.15 & 10.25 \\
\hline Overall mean (ECw) & & 476.247 & 1858.111 & 4853032.644 & 0.7350 & 3311.467 \\
\hline Overall mean (RS) & & 560.556 & 1760.056 & 1199.333 & 0.658 & 1941.142 \\
\hline
\end{tabular}

$\mathrm{ns},{ }^{*},{ }^{*}$ Respectively, not significant, significant at $\mathrm{p}<0.01$ and $\mathrm{p}<0.05 ;{ }^{1}$ Statistical analysis performed after transforming the data to $\sqrt{ } \mathrm{X}$ 
chloroplasts. Likewise, Dias \& Marenco (2007) also attribute this increase in Fo to the damage in the D1 protein, inactivating PSII. Cruz et al. (2009) conducted studies on the fluorescence of leaves of 'Ponkan' mandarin and 'Tahiti' acid lime subjected to water stress and concluded that Fo values increased proportionally to the water stress levels, corroborating the results obtained in the present study.

As to the maximum fluorescence (Fm), there were reductions of $6.13,12.26,18.39$ and $24.52 \%$, between the lowest salinity level $\left(0.6 \mathrm{dS} \mathrm{m}^{-1}\right)$ and the others $(1.2,1.8$, 2.4 and $3.0 \mathrm{dS} \mathrm{m}^{-1}$ ) respectively, corresponding to a relative decrease of $9.63 \%$ per unit increase in ECw (Figure 1B). Silva et al. (2006) comment that reductions in Fm can be related to the photoinhibition of the quinone, associating them to the inactivation of PSII in the membranes of the thylakoids, compromising the flow of electrons between the photosystems. Freire et al. (2014) observed reduction in Fm from 2256 to 2048 in leaves of yellow passion fruit when irrigation water salinity increased from 0.5 to $4.5 \mathrm{dS} \mathrm{m}^{-1}$, which is equivalent to a reduction of $9.2 \%$, similar to that observed in the present study.

Fv showed reduction of $16.59 \%$ per unit increase in ECw, with maximum point in the control treatment $\left(0.6 \mathrm{dS} \mathrm{m}^{-1}\right)$ and mean value of 1773 (Figure 1C). As salinity increased, there were absolute linear decreases of Fv corresponding to 326 electrons quantum ${ }^{-1}$ with per unit increase in ECw. Lucena et al. (2012) observed reductions in Fv of 39.89, 28.40, 24.94 and $40.39 \%$ in the mango cultivars 'Haden', 'Palmer', 'Tommy Atkins' and 'Ubá' subjected to saline stress with $45 \mathrm{mmol}_{\mathrm{c}} \mathrm{L}^{-1}$ of $\mathrm{NaCl}$ under conditions of hydroponic cultivation. The quantum efficiency of photosystem II (Fv/Fm) was maximal (0.84) when plants were irrigated with water of $0.6 \mathrm{dS} \mathrm{m}^{-1}$, with linear decreases as salinity increased; for this, the unit increase in ECw promotes reductions of $10.4 \%$ in $\mathrm{Fv} / \mathrm{Fm}$, compromising the photochemical process. The literature reports that plants under absence of stress show potential quantum yield (Fv/Fm) in the range from 0.75 to 0.85 (Corrêa \& Alves, 2010). The Fv/ Fm ratio with values below that range reflect photoinhibitory damages in the reaction centers of photosystem II. The obtained results allow inferring that, under the experimental conditions, the irrigation water with ECw above $1.8 \mathrm{dS} \mathrm{m}^{-1}$ caused damages to the photosynthetic apparatus of 'Mimo do Céu' orange, a fact evidenced by the reduction in the photochemical efficiency of PSII, 0.73. Cruz et al. (2009) observed that the lowest value in the Fv/Fm ratio was 0.320 in citrus cultivars subjected to water stress, recovering with subsequent irrigation. Silveira et al. (2010) report that plants subjected to salinity have low quantum yield, probably due to stomatal closure and decrease in photosynthesis, physiological mechanisms that may have occurred with the plants subjected to saline stress in this experiment.

As to the total production of fruits (TPF), there was significant effect $(\mathrm{p} \leq 0.01)$ of the levels of irrigation water salinity $(\mathrm{ECw})$ and the genotypes of rootstocks; however, there was no effect of the interaction ( $p>0.05$ ), indicating that the rootstocks show similar tolerance under the different levels of irrigation water salinity (Table 4).

According to the data in Figure 2A, the total production of fruits suffered decrease with the increase in ECw, with mean
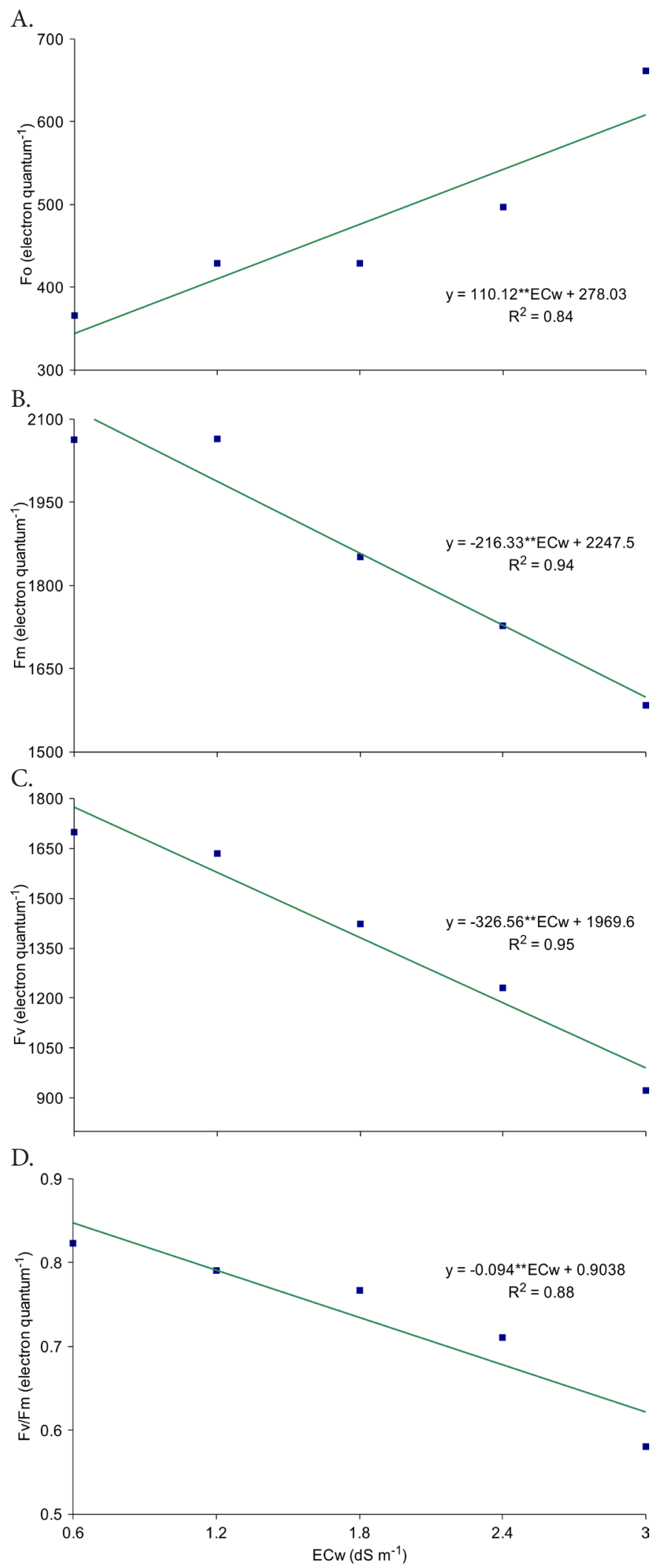

Figure 1. Parameters of chlorophyll fluorescence in "Mimo do Céu" orange (Citrus sinensis OSBECK): initial fluorescence - Fo (A), maximum fluorescence - Fm (B), variable fluorescence - Fv (C) and maximum quantum efficiency of photosystem II - Fv/Fm (D), at 150 days after the beginning of flowering subjected to saline stress under controlled conditions

reduction of $18.87 \%$ when subjected to the unit increase in electrical conductivity $\left(\mathrm{dS} \mathrm{m}^{-1}\right)$ of the irrigation water; however, 
RS2 stood out among the others with respect to production, obtaining mean of 4,255 g of fruits, superior to RS1 and RS3 in $24.21 \%(3,425 \mathrm{~g})$ and $88.9 \%(2,252 \mathrm{~g})$, respectively (Figure 2B).

Saline stress causes deleterious effects to the plant, such as osmotic deregulation, phytotoxicity and nutritional imbalance, reducing growth and, consequently, the production of photoassimilates and their allocation to the fruits (Taiz \& Zeiger, 2013), which can be evidenced in the present study, since the production of fruits, although different between scion-rootstock combinations, showed approximate reduction of $20 \%$ per unit increase in water salinity. Ashraf \& Foolad (2005) cite that, under saline conditions, $\mathrm{Na}^{+}$and $\mathrm{Cl}^{-}$are the main ions that cause

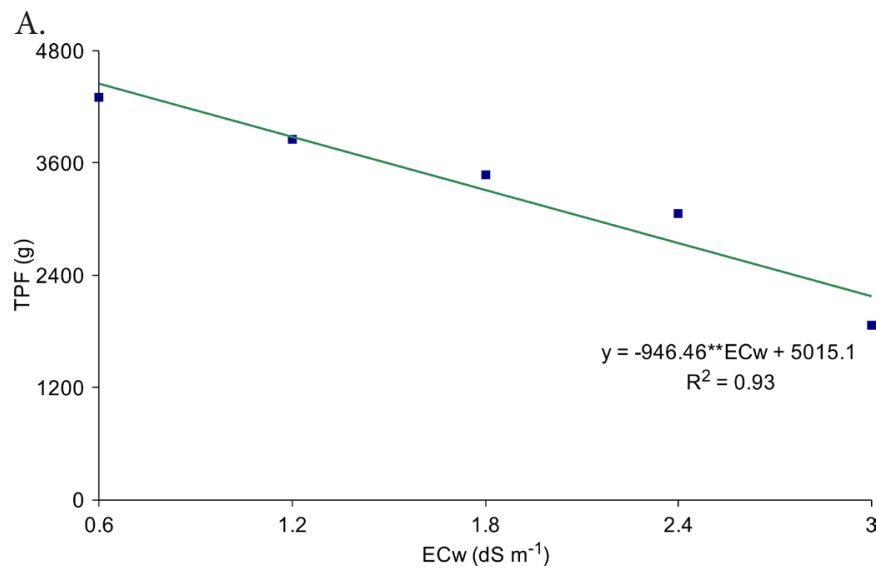

B.

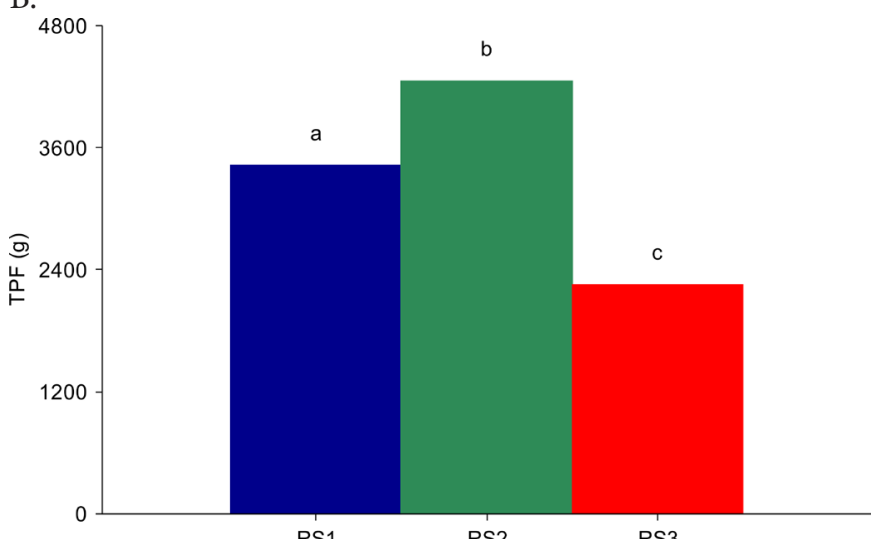

Bars of means followed by the same letter do not differ statistically by Tukey test at 0.05 probability level

Figure 2. Regression analysis for the total production of fruits of 'Mimo do Céu' orange (Citrus sinensis OSBECK) as a function of water salinity (A) and test of means (Tukey) (B) for the three rootstocks grafted with 'Mimo do Céu' orange at 150 days after the beginning of flowering physiological alterations in citrus, limiting plant growth and yield, a fact that can explain such reduction, because the waters used for irrigation were prepared using $\mathrm{NaCl}$.

Additionally, there were different behaviors between scionrootstock combinations under salinity conditions, which is common due to the genetic variability, as corroborated by Garcia-Sanchez et al. (2002), who observed variations between the different genotypes of rootstocks with respect to tolerance to salinity, as well as Balal et al. (2011), who evaluated citrus rootstocks and identified Rangpur lime as the one with highest tolerance to saline stress.

In the analysis of variance (Table 5), there was no significant effect $(p>0.05$ ) for the interaction between $\mathrm{N}$ doses and scion-rootstock combinations; for the factor $\mathrm{N}$ doses, there was significant effect on the fluorescence variables Fo and $\mathrm{Fv}(\mathrm{p} \leq 0.05)$, while for the factor rootstocks (RS), there was effect on the total production of fruits (TPF) $(p<0.01)$, whose results indicate that the higher supply of $\mathrm{N}$ fertilization did not promote increase in fruit production.

According to Figure 3, there was a reduction of $30.53 \%$ in the initial fluorescence (Fo) and increases of about 22.92, 60.25 and 26.33\% for the variables Fm, Fv and Fv/Fm, in the comparison the means from the treatment of $100 \%$ and the treatment of $200 \%$ of $\mathrm{N}$ fertilization. As discussed, the increase in the electrical conductivity of the irrigation water reduces the quantum efficiency of PSII, which is attributed to the low capacity of synthesis of proteins present in the membranes of the thylakoids. However, the increase in $\mathrm{N}$ availability may have partially lessened the effects of saline stress, notably when reduced the initial fluorescence and increased the maximum fluorescence, since, according to Epstein \& Bloom (2006), the presence of $\mathrm{N}$ in adequate amounts favors the activity of the RuBisCo protein, benefitting the transport of electrons in the membranes of the thylakoids.

According to Santos et al. (2010), well-nourished plants tend to tolerate more the effects of salinity compared with plants subjected to deficiency of some nutrient. These authors point out the importance of knowing the mechanisms involved in the absorption of nutrients in plants subjected to saline stress. Aragão et al. (2010) report that saline stress inhibits $\mathrm{N}$ use by plants, compromising absorption, distribution and assimilation, as well as the synthesis of proteins. Feijão et al. (2011) and Furtado et al. (2012) concluded that $\mathrm{N}$ is able to reduce the effects of salinity in sorghum and water melon, respectively. It is important to point out that these authors obtained these results in nutrient solutions, supplying $\mathrm{N}$ in the form of $\mathrm{NO}_{3}$.

Table 5. Summary of the analysis of variance for the variables initial fluorescence (Fo), maximum fluorescence (Fm), variable fluorescence (Fv), maximum quantum efficiency of photosystem II (Fv/Fm) and total production of fruits (TPF) under different doses of nitrogen $(\mathrm{N})$ and combinations of scion-rootstock (RS) of citrus grafted with 'Mimo do Céu' orange (Citrus sinensis OSBECK var. Mimo) at 150 days after the beginning of flowering

\begin{tabular}{|c|c|c|c|c|c|c|}
\hline \multirow{2}{*}{ Source of variation } & \multirow{2}{*}{ DF } & \multicolumn{5}{|c|}{ Mean Square } \\
\hline & & $\mathrm{Fo}^{1}$ & $\mathrm{Fm}$ & Fv & $\mathrm{Fv} / \mathrm{Fm}$ & TPF1 \\
\hline Nitrogen (N) & 1 & $183618^{\star}$ & $560740.5^{\text {ns }}$ & $1387778^{\star}$ & $0.105^{\text {ns }}$ & $107399.13^{\text {ns }}$ \\
\hline Rootstock (RS) & 2 & $20743.39^{\text {ns }}$ & $61766.89^{n s}$ & $119632.67^{\mathrm{ns}}$ & $0.014^{\mathrm{ns}}$ & $2974490.941^{* *}$ \\
\hline $\mathrm{N} \times \mathrm{RS}$ & 2 & $35668.5^{\text {ns }}$ & $61766.89^{\text {ns }}$ & $98468.67^{\mathrm{ns}}$ & $0.02^{\text {ns }}$ & $2464.898^{\mathrm{ns}}$ \\
\hline Block & 2 & 26403.39 & 29070.06 & 86 & 0.001 & 205415.235 \\
\hline Residue & 10 & 28714.39 & 187019.12 & 232686.93 & 0.024 & 34026.458 \\
\hline CV & & 14.78 & 12.47 & 22.19 & 13.28 & 9.5 \\
\hline
\end{tabular}

ns $=$ not significant; ${ }^{* \star}=$ significant at $\mathrm{p} \leq 0.01 ;{ }^{*}=$ significant at $\mathrm{p} \leq 0.05$. ${ }^{1}$ Statistical analysis performed after transforming the data to $\sqrt{ } \mathrm{X}$ 
A.

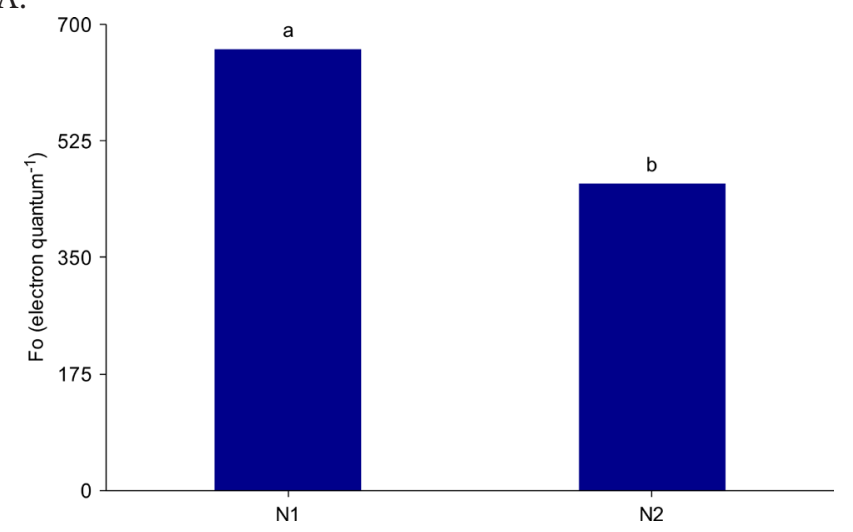

B.

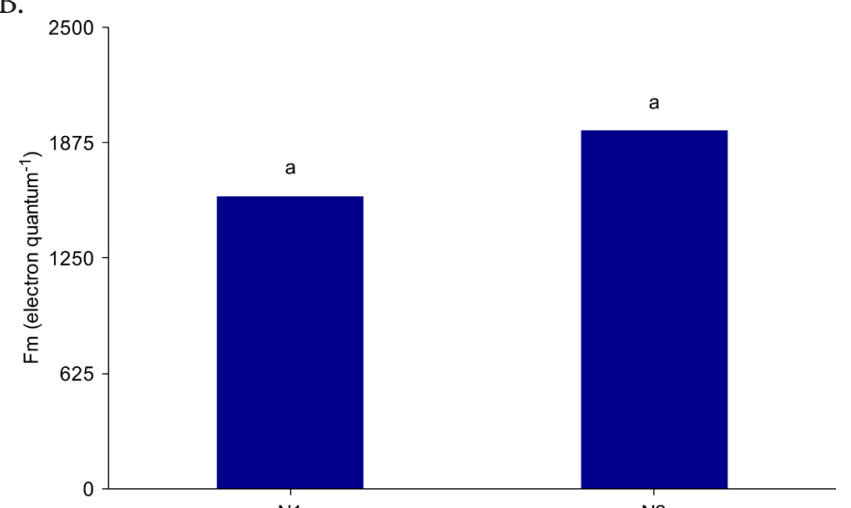

C.

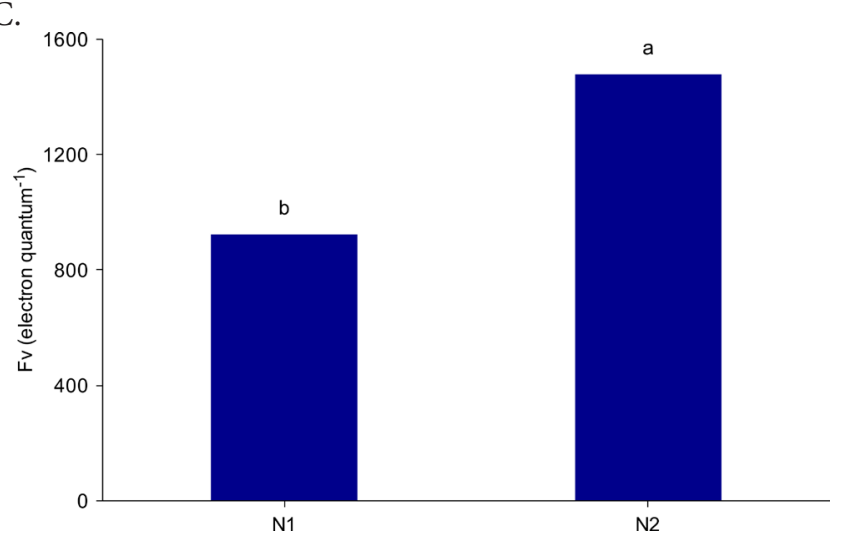

D.

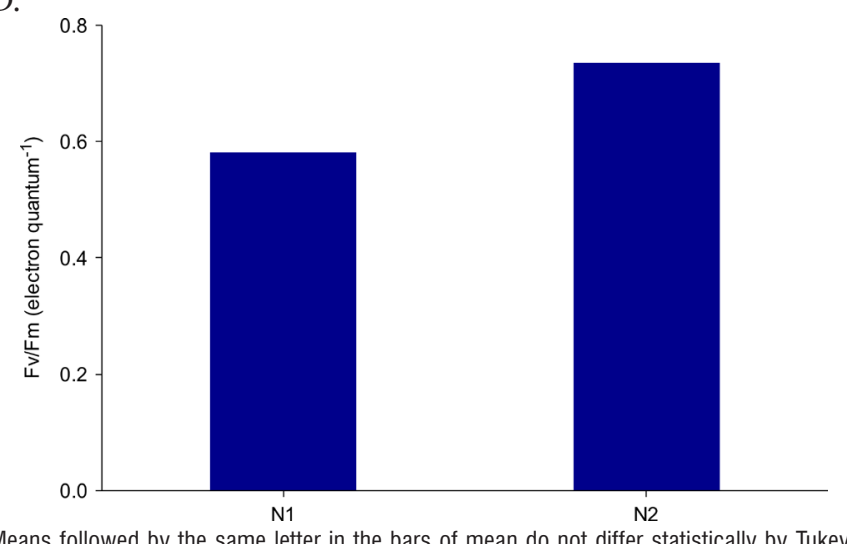

Means followed by the same letter in the bars of mean do not differ statistically by Tukey test at 0.05 probability level

Figure 3. Parameters of chlorophyll fluorescence of 'Mimo do Céu' orange (Citrus sinensis OSBECK): initial fluorescence - Fo (A), maximum fluorescence - Fm (B), variable fluorescence - Fv $(C)$ and maximum quantum efficiency of photosystem II - Fv/Fm (D) at 150 days after the beginning of flowering, subjected to saline stress (ECW 3.0 $\mathrm{dS} \mathrm{m}^{-1}$ ) and doses of nitrogen (N1 - 100\% and N2 200\%)
In the present study, in which there was beneficial effect of $\mathrm{N}$, the increase in $\mathrm{N}$ supply favored the chlorophyll fluorescence of the plants, reflecting in the total production of fruits. Plants under the treatment with $100 \%$ of the $\mathrm{N}$ dose showed mean production of $1,863 \mathrm{~g}$ per plant and, with the $200 \%$ of the $\mathrm{N}$ dose, mean production of 2,018 g per plant (Figure $4 \mathrm{~A}$ ), i.e., an increase of $8.3 \%$ in the production. This fact should be pointed out, because the conditions were of saline stress and this increment with a higher $\mathrm{N}$ dose combined with the use of an adequate RS can increase the production in the commercial cultivation. This is consistent with the production results, which, similar to Experiment I, showed significant effect ( $\mathrm{p}<$ 0.01) for the studied rootstocks, with the 'Common' Rangpur lime (RS2) obtaining production superior in 30.27 and $116.3 \%$, compared with RS1 and RS3, respectively (Figure 4B).

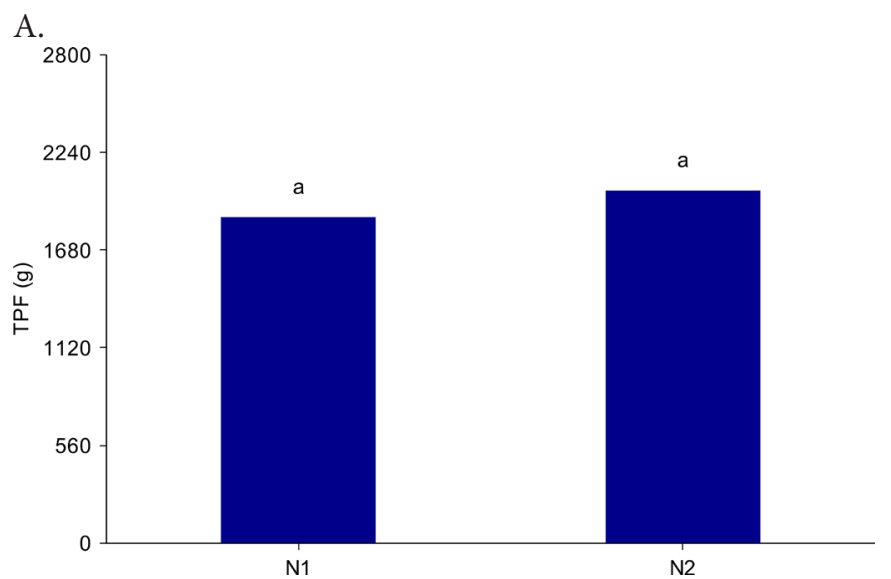

B.

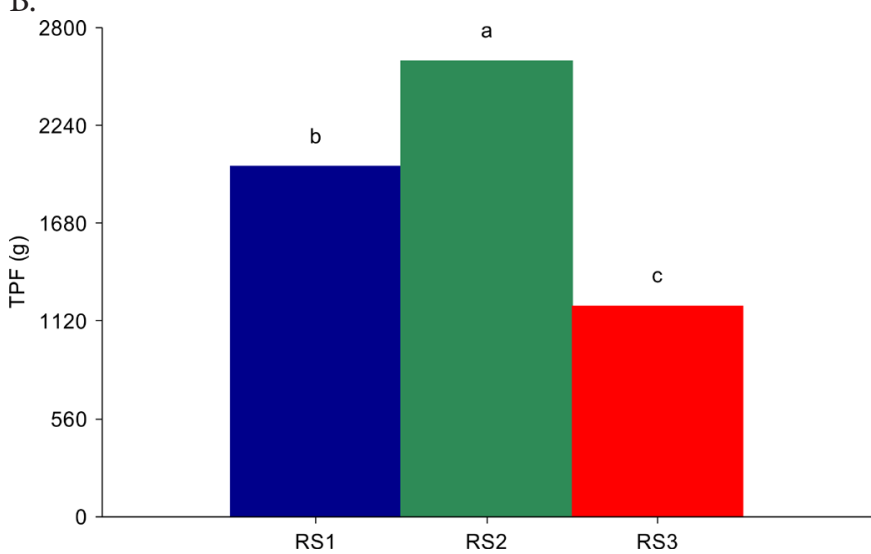

Bars of means followed by the same letter do not differ by Tukey test at 0.05 probability level Figure 4. Total production of fruits (TPF) of 'Mimo do Céu' orange (Citrus sinensis OSBECK) grafted on three rootstocks (A) at 150 days after the beginning of flowering subjected

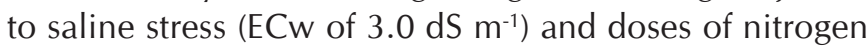
(N1 - $100 \%$ and N2 $200 \%$ )

\section{Conclusions}

1. The maximum quantum efficiency of photosystem II is inhibited in citrus plants under saline stress.

2. The increase in the level of irrigation water salinity reduces the total production of fruits in a similar way for the three evaluated genotypes.

3. 'Mimo do Céu' orange grafted with 'Common' Rangpur lime (RS2-LCRC) shows higher production potential, regardless of irrigation water salinity. 
4. The nitrogen dose above the recommendation did not promote significant increase in the production of fruits.

5. The deleterious effect of irrigation water salinity on 'Mimo do Céu' orange is best remedied by the use of the RS 'Common' Rangpur lime than by the additional application of nitrogen.

\section{Literature Cited}

Aragão, R. M.; Silveira, J. A. G.; Silva, E. N.; Lobo, A. K. M.; Dutra, A. T. B. Absorção, fluxo no xilema e assimilação do nitrato em feijão-caupi submetido à salinidade. Revista Ciência Agronômica, v.14, p.100-106, 2010.

Ashraf, M.; Foolad, M. R. Roles of glycinebetaine and proline in improving plant abiotic stress resistance. Environmental and Experimental Botany, v.59, p.206-216, 2005. http://dx.doi. org/10.1016/j.envexpbot.2005.12.006

Balal, R. M.; Ashraf, M. Y.; Khan, M. M.; Jaskani, M. J.; Ashfaq, M. Influence of salt stress on growth and biochemical parameters of citrus rootstocks. Pakistan Journal of Botany, v.43, p.2135-2141, 2011.

Brito, M. E. B.; Brito, K. S. A. de; Fernandes, P. D.; Gheyi, H. R.; Suassuna, J. F.; Soares Filho, W. S.; Melo, A. S de. Growth of ungrafted and grafted citrus rootstocks under saline water irrigation. African Journal of Agricultural Research, v.9, p.36003609, 2014. http://dx.doi.org/10.5897/2014.9039

Corrêa, M. J. P.; Alves, P. L. C. A. Efeitos da aplicação de herbicidas sobre a eficiência fotoquímica em plantas de soja convencional e geneticamente modificada. Ciência e Agrotecnologia, v.34, p.11361145, 2010. http://dx.doi.org/10.1590/S1413-70542010000500009

Cruz, M. C. M.; Siqueira, D. L.; Salomão, L. C. C.; Cecon, P. R. Fluorescência da clorofila a em folhas de tangerineira 'Ponkan' e limeira ácida 'Tahiti' submetidas ao estresse hídrico. Revista Brasileira de Fruticultura, v.31, p.896-901, 2009. http://dx.doi. org/10.1590/S0100-29452009000300037

Dias, D. P.; Marenco, R. A. Efeito da nebulosidade nos parâmetros da fluorescência em Minquartia guianensisi Aubl. Revista Brasileira de Biociências, v.5, p.54-56, 2007.

Epstein, E.; Bloom, A. J. Nutrição mineral de plantas princípios e perspectivas. Londrina: Planta, 2006. 403p.

Falco, W. F.; Botero, E. R.; Falcão, E. A.; Santiago, E. F.; Bagnato, V. S.; Caires, A. R. L. In vivo observation of chlorophyll fluorescence quenching induced by gold nanoparticles. Journal of Photochemistry and Photobiology A: Chemistry, v.225, p.65-71, 2011. http://dx.doi.org/10.1016/j.jphotochem.2011.09.027

Feijão, A. R.; Silva, J. C. B. da; Marques, E. C.; Prisco, J. T.; GomesFilho, E. Efeito da nutrição de nitrato na tolerância de plantas de sorgo sudão à salinidade. Revista Ciência Agronômica, v.42, p.675683, 2011. http://dx.doi.org/10.1590/S1806-66902011000300014

Ferreira, D. F. Sisvar: A computer statistical analysis system. Ciência e Agrotecnologia, v.35, p.1039-1042, 2011. http://dx.doi. org/10.1590/S1413-70542011000600001

Freire, J. L. O.; Dias, T. J.; Cavalcante, L. F.; Fernandes, P. D.; Lima Neto, A. J. Rendimento quântico e trocas gasosas em maracujazeiro amarelo sob salinidade hídrica, biofertilização e cobertura morta. Revista Ciência Agronômica, v.45, p.82-91, 2014. http://dx.doi. org/10.1590/S1806-66902014000100011

Furtado, G. F.; Pereira, F. H. F.; Andrade, E. M. G.; Pereira Filho, R. R.; Silva, S. S. da. Efeito do nitrato de cálcio na redução do estresse salino em melancieira. Revista Verde de Agroecologia e Desenvolvimento Sustentável, v.7, p. 33-40, 2012.
Garcia-Sanchez, M. R.; Bernet G. P.; Puchades, J.; Gomez, I.; Carbonell. E. A.; Asins, M. J. Reliable and easy screening technique for salt tolerance of citrus rootstocks under controlled environments. Australian Journal of Agricultural Research, v.53, p.653-662, 2002. http://dx.doi.org/10.1071/AR01071

Habibi, F.; Amiri, M. E. Influence of in vitro salinity on growth, mineral uptake and physiological responses of two citrus rootstocks. International Journal of Agronomy and Plant Production, v.4, p.1320-1326, 2013.

IBGE - Instituto Brasileiro de Geografia e Estatística. Sidra. Citros. $<$ http://www.sidra.ibge.gov.br>. 10 Dez 2013.

Konrad, M. L. F.; Silva, J. A. B.; Furlani, P. R.; Machado, E. C. Trocas gasosas e fluorescência da clorofila em seis cultivares de cafeeiro sob estresse de alumínio. Bragantia, v.64, p.339-347, 2005. http:// dx.doi.org/10.1590/S0006-87052005000300004

López-Climent, M. F; Arbona, A; Pérez-Clemente, R. M; Gomez-Cadenas, A. Relationship between salt tolerance and photosynthetic machinery performance in citrus. Environmental and Experimental Botany, v.62, p.176-184, 2008. http://dx.doi.org/10.1016/j.envexpbot.2007.08.002

Lucena, C. C. de; Siqueira, D. L. de; Martinez, H. E. P.; Cecon, P. R. Salt stress change chlorophyll fluorescence in mango. Revista Brasileira de Fruticultura, v.34, p. 1245-1255, 2012. http://dx.doi. org/10.1590/S0100-29452012000400034

Marchesan, E.; Grohs, M.; Santos, D. S.; Formentini, T. C.; Silva, L. S. da; Sartori, G. M. S.; Ferreira, R. B. Fontes alternativas à ureia no fornecimento de nitrogênio para o arroz irrigado. Ciência Rural, v.41, p.2053-2059, 2011. http://dx.doi.org/10.1590/S0103-84782011001200003

Novais, R. F.; Neves, J. C. L.; Barros, N. F. Ensaio em ambiente controlado. In: Oliveira, A. J. de; Garrido, W. E.; Araujo, J. D. de; Lourenço, S. Métodos de pesquisa em ambiente controlado. Brasília: Embrapa SEA, 1991. p.189-273.

Rumeau, D.; Peltier, G.; Cournac, L. Chloro respiration and cyclic electron flow around PSI during photosynthesis and plant stress response. Plant Cell Environment, v.30, p.1041-1051, 2007. http:// dx.doi.org/10.1111/j.1365-3040.2007.01675.x

Santos, R. V.; Cavalcante, L F; Vital, A. F. M. Interações salinidadefertilidade do solo. In: Gheyi, H. R.; Dias, N. da S.; Lacerda, C. F. de. Manejo da salinidade na Agricultura: Estudo básico e aplicados. Fortaleza: INCTSal, 2010. Cap.14, p.1-35.

Silva, L. A.; Brito, M. E. B.; Sá, F. V. S.; Moreira, R. C. L.; Soares Filho, W. dos S.; Fernandes, P. D. Mecanismos fisiológicos em híbridos de citros sob estresse salino em cultivo hidropônico. Revista Brasileira de Engenharia Agrícola e Ambiental, v.18, p.1-7, 2014.

Silva, M. M. P. da; Vasquez, H. M.; Bressansmith, R.; Silva, J. F. C.; Erbesdobler, E. D.; Andrade Júnior, P. S. C. Eficiência fotoquímica de gramíneas forrageiras tropicais submetidas à deficiência hídrica. Revista Brasileira de Zootecnia, v.35, p.67-74, 2006. http:// dx.doi.org/10.1590/S1516-35982006000100008

Silveira, J. A. G.; Silva, S. L. F.; Silva, E. N.; Viégas, R. A. Mecanismos biomoleculares envolvidos com a resistência ao estresse salino em plantas. In: Gheyi, H. R.; Dias, N. da S.; Lacerda, C. F. de. Manejo da salinidade na agricultura: Estudos básicos e aplicados. Fortaleza: INCTSal, 2010. Cap.11, p.161-180.

Singh, A.; Saini, M. L.; Behl, R. K. Screening of citrus rootstocks for salt tolerance in semi-arid climates - A review. Tropics, v.13, p.53-66, 2003. http://dx.doi.org/10.3759/tropics.13.53

Syvertsen, J. P.; Garcia-Sanchez, F. Multiple abiotic stresses occurring with salinity stress in citrus. Environmental and Experimental Botany, v.103. p.128-137, 2014. http://dx.doi.org/10.1016/j.envexpbot.2013.09.015

Taiz, L.; Zeiger, E. Fisiologia vegetal. Porto Alegre: ArtMed, 2013. 828p. 